Volume 13, No. 1, Juni 2014

ISSN 1411-514X (print)

ISSN 2355-7737 (online)

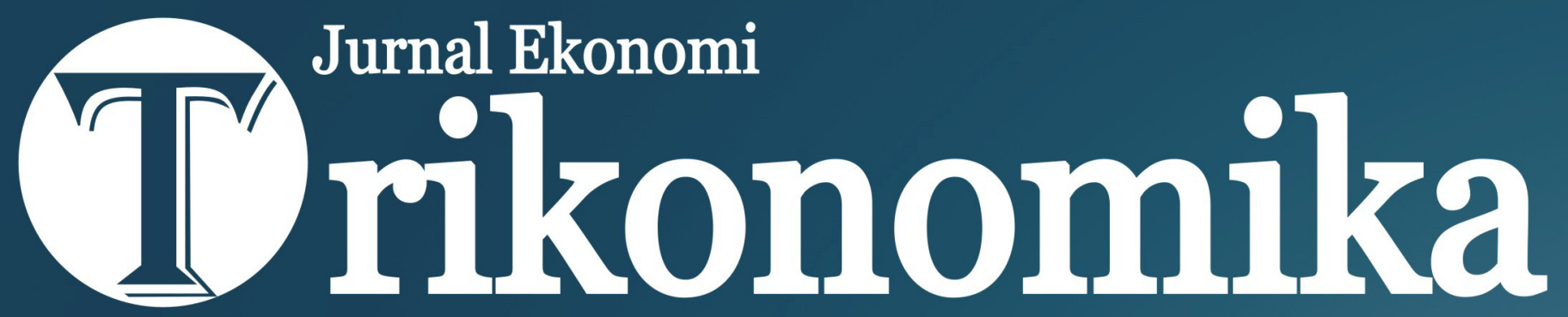


DAFTAR ISI

Trikonomika, Volume 13, No. 1, Juni 2014

Pengaruh Otonomi dan Akuntabilitas Perguruan Tinggi terhadap Kinerja Manajerial

Isnaeni Nurhayati

Keseimbangan Jangka Pendek dan Jangka Panjang Nilai Tukar Rupiah terhadap Dollar Amerika

Horas Djulius, Yudi Nurdiansyah

Kajian Kepemimpinan Transformasional, Komitmen Karyawan, Motivasi, Kepuasan Kerja, dan Kinerja Karyawan

Edy Saptono

$21-48$

Pengaruh Kualitas Pelayanan terhadap Kepuasan Mahasiswa Program Ekstensi Fakultas Ekonomi Universitas Jambi

Yenny Yuniarti

Determinan Profitabilitas Bank: Suatu Studi pada Bank yang Terdaftar di BEI

Jaja Suteja, Gerinata Ginting

Faktor Determinan Minat Wirausaha Mahasiswa Fakultas Ekonomi dan Bisnis Universitas

Negeri Gorontalo

Herwin Mopangga $78-90$

Pengaruh Upah dan Pengalaman Kerja terhadap Produktivitas Karyawan Kerajinan Ukiran Kabupaten Subang

Ardika Sulaeman

$91-100$

Analisis Harga Saham dan Rata-Rata Abnormal Return Sebelum dan Sesudah Ex-Dividend Date (Studi pada Emiten Indeks Kompas-100)

Alvin Mulya Hidayati $101-107$

Pengaruh Manajemen Laba Akrual dengan Pendekatan Revenue Discretionary Model terhadap Kinerja Perusahaan

Sepriahangga Wahyu Windharta, Nurmala Ahmar $108-118$ 


\title{
Determinan Profitabilitas Bank: Suatu Studi pada Bank yang Terdaftar di BEI
}

\author{
Jaja Suteja \\ Fakultas Ekonomi Universitas Pasundan \\ Jl. Tamansari No. 6-8, Bandung 40116 \\ E-Mail: jajasuteja@unpas.ac.id \\ Gerinata Ginting \\ Fakultas Pascasarjana Universitas Pasundan \\ Jl. Sumatera No. 41, Bandung 40117 \\ E-Mail: gerinata.ginting@yahoo.com
}

\begin{abstract}
This research is aimed at providing empirical evidence of the impact of non interest income, Non Interest Expense, Loan Loss Provisions, Equity, Total Assets, GDP, Market Capitalization on ROA. This research sampled 20 banks listed in Indonesia Stock Exchange during the research period that is 2003 to 2011. Data were analyzed using multiple regression method. Based on the result of analysis, it is concluded that Non Interest Income, Non Interest Expense, Loan Loss Provisions, Equity, Total Assets, GDP, Market Capitalization have significant effect on $R O A$.
\end{abstract}

Keywords: non interest income, non interest expense, loan loss provisions, equity, total assets, GDP, market capitalization, ROA.

\begin{abstract}
ABSTRAK
Penelitian ini bertujuan untuk memberikan bukti empiris pengaruh non interest income, non interest expense, loan loss provisions, equity, total assets, GDP, market capitalization terhadap ROA. Populasi penelitian adalah 20 perusahaan perbankan yang terdaftar di Bursa Efek Indonesia selama periode penelitian tahun 2003-2011. Data dianalisis menggunakan regresi berganda. Berdasarkan hasil pengujian disimpulkan bahwa non interest income, non interest expense, loan loss provisions, equity, total assets, GDP, market capitalization berpengaruh signifikan terhadap ROA.
\end{abstract}

Kata Kunci: non interest income, non interest expense, loan loss provisions, equity, total assets, GDP, market capitalization, ROA. 


\section{PENDAHULUAN}

Sektor perbankan merupakan tulang punggung bagi perekonomian Indonesia dan memiliki peranan yang penting sebagai perantara keuangan. Kesehatan bank memiliki pengaruh penting bagi kesehatan perekonomian secara umum, hal ini tidak hanya penting bagi para manajer bank, tetapi juga untuk stakeholder seperti, bank sentral, asosiasi bankir, pemerintah dan otoritas keuangan lainnya. Pengetahuan tentang faktor-faktor ini akan bermanfaat dalam membantu pihak yang berwenang dan manajer bank dalam merumuskan kebijakan-kebijakan masa depannya dalam meningkatkan keuntungan dari sektor perbankan Indonesia.

Keuntungan merupakan tujuan utama yang harus dicapai oleh setiap bank dalam melakukan kegiatan usaha perbankan. Modal bank akan bertambah yang pada gilirannya akan meningkatkan kemampuan bank dalam melakukan operasinya. Keuntungan yang diperoleh selain ditentukan oleh kemampuan bank itu sendiri, juga tidak lepas dari kepercayaan para pemegang saham dan masyarakat yang menyimpan dananya berupa giro, tabungan, maupun deposito, serta dipengruhi juga oleh faktor eksternal yang tidak dapat dipengaruhi oleh bank.

Dunia perbankan di Indonesia telah mengalami berbagai situasi dan kondisi, salah satu yang tidak dapat dilupakan adalah pada masa krisis perbankan yang terjadi pada tahun 1997-1998, peristiwa tersebut telah memberikan pelajaran berharga bahwa berbagai permasalahan di sektor perbankan yang tidak terdeteksi secara dini akan mengakibatkan runtuhnya kepercayaan masyarakat terhadap industri perbankan. Selain itu, upaya pemulihan kondisi perbankan nasional dan peningkatan kembali kepercayaan masyarakat terhadap industri perbankan memerlukan biaya yang tidak sedikit.
Penarikan dana masyarakat secara besar-besaran dalam waktu singkat memberikan dampak negatif pada aspek likuiditas bank. Hal ini apabila tidak segera ditangani akan menimbulkan permasalahan lanjutan berupa permasalahan solvabilitas, karena bank akan terpaksa memberikan insentif bunga simpanan yang sangat tinggi untuk mempertahankan simpanan masyarakat dan seringkali insentif jauh berada di atas kemampuan bank, dengan pendapatan yang relatif terbatas, struktur biaya bunga yang tinggi akan mengurangi rentabilitas bank, bahkan mengakibatkan kerugian yang luar biasa seperti yang pernah terjadi pada industri perbankan Indonesia dalam kurun waktu 1997-1998. Sementara itu, dari sisi penyaluran dana, komposisi aktiva produktif juga turut menentukan ketahanan bank dalam menghadapi permasalahan yang berasal dari faktor eksternal perbankan.

Pada Gambar 1. dapat dilihat perkembangan perbankan di Indonesia pasca krisis 1998 mengalami pertumbuhan yang pesat, meskipun pada tahun 2008, dunia dihadapkan pada krisis keuangan global yang telah memorakporandakan stabilitas sistem keuangan di berbagai negara maju. Namun daya tahan sistem keuangan domestik, khususnya industri perbankan juga cukup mantap sebagai hasil dari upaya penguatan sistem perbankan yang dilakukan sejak krisis tahun 1998.

Terjaganya stabilitas tersebut memberikan landasan yang cukup kondusif bagi perekonomian domestik melalui dukungan pembiayaan ekonomi yang meningkat signifikan. Eksposur atau dampak keuangan potensial yang berlipat ganda, karena adanya probabilitas terjadinya perbedaan antara kenyataan dengan harapan (risiko) perbankan dan lembaga keuangan Indonesia terhadap subprime mortgage relatif minimal. Hal itu menyebabkan gejolak pada sistem keuangan di Indonesia tidak separah negaranegara lain yang terkena dampak krisis.

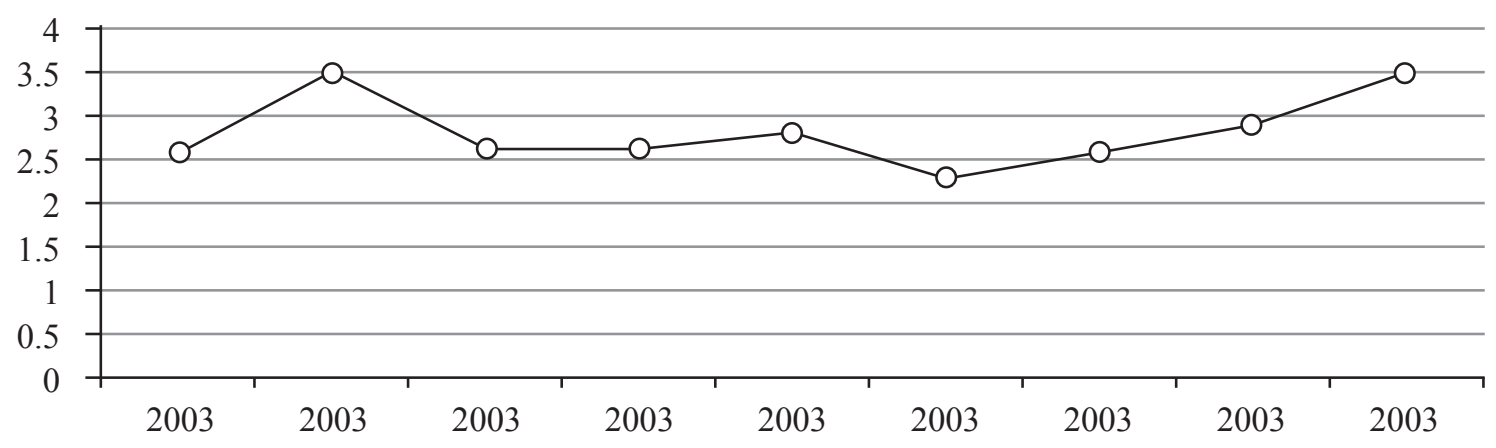

Gambar 1. ROA Perbankan di Indonesia

Periode 2003-2011 
Terdapat banyak faktor yang dapat mempengaruhi tingkat profitabilitas bank, selain dari sisi internal bank terdapat pula faktor eksternal yang tidak dapat dikendalikan oleh perusahaan yang dapat mempengaruhi tingkat profitabilitas bank, di dalam penelitian Sufian and Chong (2008) mengenai faktor yang menentukan tingkat profitabilitas pada nagara berkembang, dengan studi kasus pada negara Filipina, melakukan penelitian mengenai bagaimana pengaruh non interest income, non interest expense, loan loss provisions, equity, total asset, money supply, inflation, growth gdp, market capitalization terhadap return on assets (ROA).

Pendapatan memiliki peranan yang sangat besar terhadap tingkat profit suatu perusahaan. Perbankan memiliki dua sumber pendapatan, yaitu pendapatan bunga (interest income) dan pendapatan selain bunga (non interest income). Pendapatan terbesar dan utama pada sektor perbankan didapat dari pendapatan bunga, hal ini karena kegiatan utama bank adalah menghimpun dana dan menyalurkan kredit.

Namun dalam beberapa waktu terakhir beberapa peneliti seperti, Staikouras et al. (2003), Sufian and Chong (2008) memiliki pendapat bahwa dalam beberapa tahun terakhir lembaga keuangan terutama perbankan telah semakin meningkatkan pendapatan yang didapat selain dari bunga. Hal ini juga dapat dilihat di Indonesia, rasio total pendapatan bunga terhadap total pendapatan operasional sepuluh bank beraset terbesar di Indonesia mengalami tren penurunan, sedangkan tren pendapatan non bunga terus meningkat (www.lppi.or.id). Menurut Departemen Riset IFT, tren ini menunjukkan operasional aktivitas non bunga atau fee based income bank seperti provisi, komisi, laba/rugi kurs, recovery asset, transaksi derivatif, efek-efek dan lainnya telah menopang pendapatan operasional perbankan. Tren kenaikan pendapatan non bunga tersebut juga diakibatkan oleh kompetisi dalam penyaluran kredit perbankan yang semakin ketat, sehingga profitibilitas yang diperoleh perbankan dari kredit berkurang.

Penelitian Sufian and Chong (2008) menggunakan non interest expense, yang sebagian besar merupakan biaya gaji, upah, serta biaya untuk menjalankan fasilitas kantor cabang, untuk melihat sejauh mana pengaruh efisiensi manajemen yang dilakukan bank serta penggunaan teknologi seperti, ATM, dan sarana otomatis lainnya yang sekarang berkembang dengan pesat terhadap tingkat profitabilitas perbankan.
Selain dari sisi pendapatan dan pengeluaran, profitabilitas perbankan juga dipengaruhi oleh risiko yang dihadapi perbankan, di dalam menjalankan kegiatan usahanya kegiatan perbankan sebagian besar berhubungan dengan bunga, begitu pula dengan risiko yang dihadapi, risiko kredit merupakan risiko terbesar di dalam dunia perbankan. Risiko tersebut berupa gagalnya atau tidak terbayarnya kredit pinjaman yang telah diberikan bank kepada nasabah, sehingga menyebabkan bank tidak menerima kembali dana tersebut, atau sering disebut kredit macet.

Untuk mengantisipasi dampak dari terjadinya kredit macet, maka Bank Indonesia mewajibkan setiap bank untuk membentuk loan loss provisions atau penyisihan aktiva produktif, yang merupakan cadangan yang dibentuk dengan cara membebani laba rugi tahun berjalan, untuk menampung kerugian yang mungkin timbul sebagai akibat dan tidak diterimanya kembali sebagian atau seluruh aktiva produktif (Sholihin, 2010) Menurut Sufian and Chong (2008) loan loss provisions digunakan sebagai variabel yang dapat menjelaskan risiko pada perbankan.

Menurut Sufian and Chong (2008) variabel internal lainnya yang berpengaruh terhadap profitabilitas perbankan adalah total assets dan modal (equity). Total assets sebagai proxy dari ukuran bank (size) digunakan untuk melihat bagaimana ukuran besar kecilnya sebuah bank ikut berpengaruh terhadap profitabilitas bank, karena di setiap negara, bank-bank memiliki total assets yang berbeda-beda. Bahkan di Indonesia menurut Statistik Perbankan Bank Indonesia, 10 bank dengan assets terbesar di Indonesia menguasai 63,3\% dari total assets perbankan di Indonesia, sedangkan equity digunakan untuk melihat bagaimana pengaruh kekuatan modal yang dimiliki bank untuk menunjang dalam mendapatkan profitabilitas.

Selain dari sisi internal bank itu sendiri, terdapat pula faktor eksternal yang dapat mempengaruhi perbankan dalam memperoleh profit, dalam penelitiannya Sufian and Chong (2008) menggunakan variabel gross domestic product (GDP) untuk melihat bagaimana pertumbuhan perekonomian di suatu negara mempengaruhi tingkat profitabilitas perbankan, karena aktivitas perekonomian akan mempengaruhi kinerja perbankan, diantaranya mempengaruhi permintaan dan penawaran kredit serta simpanan dana pihak ketiga, yang selanjutnya akan mempengaruhi kualitas kredit. Selain dilihat dari pengaruh pertumbuhan ekonomi, dilihat juga 
bagaimana pengaruh situasi pasar modal terhadap profitabilitas perbankan, untuk melihat bagaimana kondisi pasar modal menurut Sufian and Chong (2008) dapat digunakan kapitalisasi pasar (market capitalization) sebagai proxy untuk melihat kondisi pasar modal di suatu Negara.

Return on assets (ROA) memiliki peranan yang sangat penting dalam kinerja keuangan suatu perusahaan atau perbankan. Kondisi baik buruknya suatu perusahaan bisa dilihat secara cepat melalui posisi ROA, apabila nilai ROA cukup besar, maka semakin besar pula tingkat keuntungan yang dicapai bank tersebut dan semakin pula posisi bank dari segi penggunaan aset. Menurut Surat Edaran Bank Indonesia tahun 2004, ROA yang baik nilainya lebih dari 1,25\% (Margaretha, 2006).

Berdasarkan latar belakang di atas, maka rumusan masalah dalam penelitian ini adalah apakah non interest income, non interest expense, loan loss provisions, equity, total assets, GDP, market capitalization berpengaruh terhadap ROA. Tujuan penelitian ini adalah untuk memperoleh bukti empiris pengaruh non interest income, non interest expense, loan loss provisions, equity, total assets, GDP, market capitalization terhadap ROA.

\section{Pengaruh Non Interest Income terhadap Profitabilitas}

Non interest income merupakan variabel yang dapat menjelaskan mengenai diversifikasi bisnis atau kegiatan usaha lain yang dilakukan bank selain dari bunga. Selain untuk meningkatkan pendapatan, non interest income juga dapat berfungsi untuk mengurangi risiko dengan melakukan diversifikasi pada berbagai usaha. Menurut Staikouras, et al. (2003) dalam beberapa tahun terakhir bank telah semakin memfokuskan kegiatan usahanya kepada kegiatan-kegiatan selain bunga, bank berusaha memaksimalkan fee dibanding dengan bunga. Hal ini dikarenakan semakin ketatnya persaingan di dunia perbankan, sehingga bank-bank berusaha untuk meningkatkan pendapatannya dengan menciptakan inovasi-inovasi baru berupa jasa dan fasilitas lain yang diberikan kepada nasabah yang bertujuan untuk mendapatkan fee yang pada akhirnya diharapkan akan meningkatkan pendapatan perusahaan. Dengan semakin bertambahnya pendapatan yang berasal dari non interest income, maka akan meningkatkan tingkat profitabilitas (ROA) bank. Sufian and Chong (2008) di dalam penelitian berpendapat, bahwa dalam beberapa tahun terakhir lembaga keuangan terutama perbankan telah semakin meningkatkan pendapatan yang didapat selain dari bunga, dan hasil yang diperoleh dalam penelitiannya, yaitu non interest income berpengaruh positif terhadap profitabilitas perbankan.

\section{Pengaruh Non Interest Expense terhadap Profitabilitas}

Non interest expense pada perusahaan terutama perbankan dapat menjelaskan atau memperlihatkan mengenai efisiensi manajemen dari sebuah perusahaan. Bank bertujuan untuk lebih produktif dan efisien dalam meminimalkan biaya operasi mereka, pengurangan biaya dapat meningkatkan efisiensi, sehingga dapatmeningkatkan profitabilitas perbankan. Selain itu, penggunaan teknologi elektronik baru, seperti ATM dan sarana otomatis lainnya dari jasa pengiriman, mungkin telah menyebabkan biaya upah turun, karena apabila non interest expense yang tinggi akan menyebabkan biaya yang harus dikeluarkan bank meningkat dan pada akhirnya akan mengurangi tingkat profitabilitas bank, sehingga non interest expense memiliki dampak negatif terhadap profitabilitas bank, namun Molyneux dan Thornton (1992) dalam penelitiannya mendapatkan hubungan yang positif, ini menunjukkan bahwa keuntungan yang tinggi yang diperoleh oleh perusahaan dapat disesuaikan dalam bentuk pengeluaran gaji yang lebih tinggi yang dibayarkan kepada tenaga kerja yang produktif.

\section{Pengaruh Loan Loss Provisions terhadap Profitabilitas}

Rasio loans loss provisions to total assets merupakan variabel yang dapat menjelaskan mengenai risiko kredit, pengaruh loans loss provisions terhadap tingkat profitabilitas bank diharapkan negatif, hal ini karena kredit macet dapat mengurangi profitabilitas dan perbankan harus menyisihkan dananya untuk membentuk penyisihan aktiva produktif (loan loss provisions). Tingginya loans loss provisions menandakan tingkat kualitas kredit yang rendah yang menyebabkan tingginya tingkat gagal bayar/kredit macet yang terjadi, sehingga akan menyebabkan kerugian dan memberikan dampak negatif terhadap profitabilitas.

Jiang et al. (2003) dalam penelitiannya menyimpulkan bahwa rasio loan loss provison/total aset memiliki pengaruh negatif terhadap tingkat profitabilitas pada perbankan di Hongkong. Hasil 
yang sama juga diperoleh oleh Sufian and Chong (2008) dalam penelitiannya di Filipina, rasio loan loss provisions to total asset berpengaruh negatif terhadap ROA, hal itu karena bank dengan risiko kredit yang lebih tinggi cenderung menunjukkan tingkat profitabilitas yang lebih rendah.

\section{Pengaruh Equity terhadap Profitabilitas}

Struktur modal yang kuat sangat penting bagi lembaga keuangan di negara berkembang, hal ini karena kekuatan modal memberikan kekuatan tambahan untuk bertahan apabila terjadi krisis keuangan dan meningkatkan keamanan bagi para deposan selama kondisi makro ekonomi tidak stabil. Selain itu, rasio modal yang lebih rendah di bidang perbankan menandakan leverage dan risiko yang lebih tinggi, sehingga mengakibatkan biaya pinjaman yang lebih besar. Dengan demikian, bank yang memiliki kapitalisasi besar seharusnya memiliki tingkat profitability yang lebih besar.

Kaya (2002) di dalam penelitiannya menyatakan bahwa rasio ekuitas terhadap aset memiliki dampak positif terhadap profitabilitas bank (ROA). Abreu and Mendes (2002), melakukan penelitian di negara Portugal, Jerman, Spanyol dan Perancis pada periode 1986-1999 dan menyimpulkan bahwa rasio ekuitas terhadap total aset mempengaruhi ROA secara positif.

\section{Pengaruh Total Assets terhadap Profitabilitas}

Ukuran bank pada umumnya digunakan melihat potential economies atau diseconomies of scale. Variabel ini dapat memberikan dampak yang berbeda terhadap profitabilitas bank. Faktor pertama, bisa menyebabkan hubungan positif antara size bank dan profitabilitas bank, jika ada skala ekonomi yang signifikan. Kedua, dapat menyebabkan hubungan negatif jika peningkatan diversifikasi menyebabkan risiko kredit yang lebih rendah, sehingga dapat menghasilkan pendapatan lebih rendah.

Eichengreen and Gibson (2001) menunjukkan bahwa pengaruh ukuran bank tumbuh pada profitabilitas yang mungkin positif sampai batas tertentu. Di luar titik ini, dampak dari ukurannya bisa negatif, karena faktor birokrasi dan lainnya. Menurut Sufian and Chong (2008) variabel LNTA dapat menjelaskan mengenai ukuran untuk menangkap keuntungan biaya yang mungkin terkait dengan ukuran (skala ekonomi). Dalam literatur, terdapat hubungan campuran yang dapat ditemukan antara size bank dan profitabilitas, sedangkan dalam beberapa kasus hubungannya berbentuk U. Size bank juga dapat digunakan untuk mengendalikan perbedaan biaya dan kemampuan diversifikasi, karena bank yang lebih besar dapat lebih meminimalisasi biaya dan kemampuan diversifikasi yang lebih besar. Pada intinya, LNTA mungkin memiliki efek positif pada profitabilitas bank jika ada skala ekonomi yang signifikan. Di sisi lain, jika diversifikasi meningkat mengarah pada risiko yang lebih tinggi, variabel mungkin menunjukkan efek negatif

\section{Pengaruh Gross Domestic Product terhadap Profitabilitas}

Gross Domestic Product (GDP) merupakan salah satu indikator ekonomi makro yang paling sering digunakan untuk mengukur aktivitas total ekonomi suatu perekonomian. GDP akan mempengaruhi berbagai faktor yang terkait dengan penawaran dan permintaan terhadap pinjaman, tabungan, giro, dan deposito. Ketika pertumbuhan GDP melambat terutama ketika resesi, kualitas kredit akan memburuk menyebabkan default meningkat, sehingga mengurangi tingkat profitabilitas perbankan, begitu pula sebaliknya jika pertumbuhan GDP meningkat, maka menandakan perekonomian sedang tumbuh, permintaan kredit akan meningkat, kualitas kredit membaik, sehingga pada akhirnya akan meningkatkan profitabilitas perbankan.

Flamini et al. (2009) menyatakan kinerja perbankan cukup sensitif terhadap variabel kontrol makro ekonomi. Dengan menggunakan pertumbuhan GDP sebagai variabel makro ekonomi, memiliki pengaruh positif terhadap profitabilitas bank. Dalam penelitian Jiang et al. (2003) menyimpulkan bahwa melambatnya pertumbuhan GDP riil memberikan efek negatif terhadap profitabilitas perbankan di Hongkong. Dengan kata lain, GDP berpengaruh positif terhadap profitabilitas perbankan.

\section{Pengaruh Market Capitalization terhadap Profitabilitas}

Kapitalisasi pasar (market capitalization) dapat mencerminkan saling melengkapi atau substitusi antara bank dan pembiayaan pasar modal. Dengan kata lain, market capitalization dapat memberikan dua pengaruh yang berbeda terhadap profitabilitas, apabila dampak subtitusi lebih dominan, maka suatu negara yang memiliki pasar saham yang relatif berkembang dengan baik dapat menggantikan 
pembiayaan bank dandapat mengurangi dana pihak ketiga dari nasabah, sehingga akan memberikan pengaruh negatif terhadap profitabilitas bank, namun jika dampak saling melengkapi lebih dominan, maka market capitalization akan memberikan pengaruh positif terhadap profitabilitas bank.

Menurut Dietrich and Wanzenried (2009) di satu sisi, peningkatan kapitalisasi pasar saham dapat diartikan sebagai indikator untuk disintermediasi keuangan dan pertumbuhan pembiayaan berbasis pasar. Ancaman subtitusi keuangan bank dengan keuangan berbasis pasar dapat mengakibatkan penurunan margin bunga yang pada akhirnya akan mengurangi keuntungan bank. di sisi lain, terdapat pula hubungan positif antara kapitalisasi pasar dengan profitabilitas bank, sebagai bank Swiss banyak menawarkan kegiatan perdagangan sebagai layanan tambahan kepada pelanggan mereka.

\section{Hipotesis}

Berdasarkan uraian tersebut, dalam penelitian ini diajukan hipotesis sebagai berikut 1) Non interest income to total assets berpengaruh positif terhadap profitabilitas; 2) Non interest expense to total assets berpengaruh negatif terhadap profitabilitas; 3) Loan loss provision to total loans berpengaruh negatif terhadap profitabilitas; 4) Total asset berpengaruh negatif terhadap profitabilitas; 5) Equity to total assets berpengaruh positif terhadap profitabilitas; 6) GDP berpengaruh positif terhadap profitabilitas; 7) Stock Market Capitalization berpengaruh negatif terhadap profitabilitas; dan 8) Non interest income to total assets, non interest expense to total assets, loan loss provision to total loans, total assets, equity to total assets, GDP, stock market capitalization berpengaruh terhadap profitabilitas.

Tabel 1. Operasionalisasi Variabel

\begin{tabular}{|c|c|c|c|}
\hline Variabel & Konsep Variabel & Proksi & Ukuran \\
\hline $\begin{array}{l}\text { Non Interest Income to Total } \\
\text { Asset }\left(\mathrm{X}_{1}\right)\end{array}$ & $\begin{array}{l}\text { Variabel yang dapat menjelaskan mengenai diversifikasi } \\
\text { bisnis atau kegiatan usaha lain yang dilakukan bank selain } \\
\text { dari bunga (Sufian and Chong; 2008). }\end{array}$ & $\begin{array}{l}\text { (Non Interest Income/ } \\
\text { Total Asset) } \times 100 \%\end{array}$ & Rasio \\
\hline $\begin{array}{l}\text { Non Interest Expense to } \\
\text { Total Asset }\left(\mathrm{X}_{2}\right)\end{array}$ & $\begin{array}{l}\text { Beban non bunga yang harus dibayarkan perusahaan dalam } \\
\text { menjalankan segala kegiatan operasionalnya, pada umumnya } \\
\text { beban paling besar yang harus dikeluarkan perusahaan, yaitu } \\
\text { biaya gaji dan upah (Sufian and Chong; 2008). }\end{array}$ & $\begin{array}{l}\text { (Non Interest Expense/ } \\
\text { Total Asset) } \times 100 \%\end{array}$ & Rasio \\
\hline $\begin{array}{l}\text { Loan Loss Provisions to Total } \\
\text { Assets }\left(\mathrm{X}_{3}\right)\end{array}$ & $\begin{array}{l}\text { Variabel yang menjelaskan tingkat risiko kredit, yaitu sebuah } \\
\text { beban atau dana yang harus disisihkan bagi bank untuk } \\
\text { menutupi kerugian di masa depan atas pinjaman default } \\
\text { (Siamat, 2001). }\end{array}$ & $\begin{array}{l}\text { (Loan Loss Provisions/ } \\
\text { Total Loans) } \times 100 \%\end{array}$ & Rasio \\
\hline Equity to Total Asset $\left(\mathrm{X}_{4}\right)$ & $\begin{array}{l}\text { Besarnya kepentingan/hak pemilik perusahaan pada harta } \\
\text { perusahaan atau bisa pula diartikan sebagai kekayaan bersih } \\
\text { yang dimiliki suatu perusahaan (Riyanto, 2001). }\end{array}$ & $\begin{array}{l}\text { (Total Equity/Total } \\
\text { Asset) } \times 100 \%\end{array}$ & Rasio \\
\hline Total Assets $\left(\mathrm{X}_{5}\right)$ & $\begin{array}{l}\text { Ukuran besar atau kecilnya sebuah bank, dapat dilihat } \\
\text { dengan seberapa besar nilai keseluruhan aset yang dimiliki } \\
\text { suatu bank (Miskhin, 2011). }\end{array}$ & Ln Total Asset & Rasio \\
\hline Gross Domestic Product $\left(\mathrm{X}_{6}\right)$ & $\begin{array}{l}\text { Nilai keseluruhan semua barang dan jasa yang diproduksi di } \\
\text { dalam wilayah suatu negara dalam jangka waktu tertentu, } \\
\text { biasanya per tahun (Arifin dan Hadi W., 2007). }\end{array}$ & $\begin{array}{l}\left(G^{\prime} P_{n+1}-G D P_{n}\right) / G D P_{n} \\
\times 100 \%\end{array}$ & Rasio \\
\hline Market Capitalization $\left(\mathrm{X}_{7}\right)$ & $\begin{array}{l}\text { Hasil perkalian harga saham dan jumlah saham yang } \\
\text { dicatatkan di bursa (Manurung, 2009). }\end{array}$ & $\begin{array}{l}\text { Harga Saham } \times \text { Jumlah } \\
\text { Saham yang Beredar }\end{array}$ & Rasio \\
\hline Return on Asset (Y) & $\begin{array}{l}\text { Perbandingan antara laba sebelum pajak dengan total aset } \\
\text { dalam suatu periode (Husnan dan Pudjiastuti, 2004). }\end{array}$ & $\begin{array}{l}\text { (Laba Sebelum Pajak/ } \\
\text { Total Aset) } \times 100 \%\end{array}$ & Rasio \\
\hline
\end{tabular}




\section{METODE}

\section{Rancangan Penelitian}

Jenis penelitian ini merupakan basic research dengan pendekatan kuantitatif, yaitu penelitian dengan menggunakan hipotesis dengan menggunakan alat uji statistik untuk menyimpulkan hipotesis yang menggunakan causal hypothesis. Explanatory hypothesis atau causal hypothesis adalah hipotesis yang menyatakan hubungan satu variabel yang menyebabkan perubahan variabel lain (Sekaran, 2007).

\section{Operasionalisasi Variabel}

Definisi operasional diperlukan agar konsep yang digunakan dapat diukur secara empiris serta menghindari terjadinya kesalahpahaman dalam penafsiran yang berbeda. Definisi operasional dalam penelitian ini dapat dilihat pada Tabel 1 .

\section{Populasi}

Populasi yang digunakan dalam penelitian ini adalah semua perusahaan perbankan yang terdaftar di Bursa Efek Indonesia (BEI) yang berjumlah 20 perusahaan perbankan dari tahun 2003-2011. Adapun daftar perusahaannya dapat dilihat pada Tabel 2 .

Tabel 2. Daftar Bank yang Terdaftar di BEI Periode 2003-2011

\begin{tabular}{cl}
\hline No. & \multicolumn{1}{c}{ Nama Bank } \\
\hline 1. & Bank Arta Graha Internasional \\
2. & Bank Agroniaga \\
3. & Bank Central Asia (BCA) \\
4. & Bank CIMB Niaga \\
5. & Bank Danamon \\
6. & Bank ICB Bumiputera \\
7. & Bank Internasional Indonesia (BII) \\
8. & Bank Kesawan \\
9. & Bank Mandiri \\
10. & Bank Mayapada \\
11. & Bank Mega \\
12. & Bank Negara Indonesia (BNI) \\
13. & Bank Nusantara Parahyangan \\
14. & Bank OCBC NISP \\
15. & Bank Panin \\
16. & Bank Permata \\
17. & Bank Pundi Indonesia \\
18. & Bank Rakyat Indonesia (BRI) \\
19. & Bank Swadesi \\
20. & Bank Victoria Internasional \\
\hline
\end{tabular}

\section{Teknik Analisis}

Penelitian ini menguji pengaruh beberapa variabel yaitu non interest income, non interest expense, loan loss provisions, equity, total assets, GDP, market capitalization terhadap ROA. Pengujian terhadap rumusan menggunakan metode analisis regresi berganda. Tahap pertama adalah uji asumsi klasik untuk membuktikan bahwa model yang digunakan adalah normal dan tidak mengandung gejala multikolinearitas, autokorelasi, dan heteroskedastisitas. Kemudian, dilakukan uji untuk melihat pengaruh variabel independen terhadap variabel dependen.

\section{Model Analisis}

Model yang digunakan dalam penelitian ini adalah analisis regresi berganda. Model regresi yang dikembangkan untuk menguji hipotesis-hipotesis dirumuskan adalah:

$$
\begin{aligned}
\mathrm{ROA}_{\mathrm{t}}= & \beta_{0}+\beta_{1} \mathrm{NII} / \mathrm{TA} \mathrm{t}_{\mathrm{t}}+\beta_{2} \mathrm{NIE} / \mathrm{TA} \\
& +\beta_{3} \mathrm{LLP}_{\mathrm{t}} \mathrm{TL}_{\mathrm{t}}+ \\
& \beta_{4} \mathrm{LNTA}_{\mathrm{t}}+\beta_{5} \mathrm{EQASS}_{\mathrm{t}}+\beta_{6} \mathrm{LNGDP}_{\mathrm{t}}+ \\
& \beta_{7} \text { LNMKTCAP }_{\mathrm{t}}+\varepsilon_{\mathrm{t}}
\end{aligned}
$$

Di mana:

$\begin{array}{ll}\text { ROA } & : \text { Return on Assets } \\ \beta_{0} & : \text { Konstanta } \\ \beta_{1-8} & : \text { Koefisien Regresi } \\ \text { NII/TA } & : \text { Non Interest Income/Total Assets } \\ \text { NIE/TA } & : \text { Non Interest Expense/Total Assets } \\ \text { LLP/TL } & : \text { Loan Loss Provisions/Total Loans } \\ \text { LNTA } & : \text { Natural Logarithm of Total Assets } \\ \text { EQASS } & : \text { Equity/Total Assets } \\ \text { LNGDP } & : \text { Growth Gross Domestic Products } \\ \text { LNMKTCAP } & \text { Natural Logarithm of Stock Market } \\ & \text { Capitalization } \\ \varepsilon & : \text { Error }\end{array}$

\section{HASIL}

\section{Deskripsi Hasil Penelitian}

Ditinjau dari sebaran datanya, hasil uji statistik desktiptif menunjukkan bahwa variabel Return on Assets (ROA) mempunyai nilai rata-rata (mean) sebesar 1,622 dengan standar deviasi sebesar 1.9276069, hal tersebut mencerminkan bahwa kemampuan perusahaan dalam memperoleh profit dari kegiatan usahanya sangat baik karena perusahaan mampu mendapatkan keuntungan yang positif. Nilai standar deviasi yang lebih tinggi dari nilai mean menunjukkan bahwa secara umum bank-bank yang 
terdaftar di BEI pada periode penelitian memiliki nilai Return On Assets (ROA) yang bervariasi atau bisa dikatakan memiliki selisih/penyimpangan yang tinggi dari nilai rata-ratanya.

Ratio non interest income to total assets mempunyai nilai rata-rata (mean) sebesar 1.169 dengan standar deviasi sebesar 0.7468 , sedangkan $n o n$ interest expense to total assets mempunyai nilai ratarata (mean) sebesar 3.57222 dengan standar deviasi sebesar 1.3186784, hal tersebut mencerminkan bahwa kemampuan perusahaan untuk mendapatkan pendapatan selain dari bunga masih relatif rendah, karena nilai mean yang masih dikisaran 1.169, sedangkan pengeluaran perusahaan selain bunga cukup besar karena nilai rata-rata yang di atas 3.5, sehingga pendapatan selain dari bunga lebih kecil daripada pengeluaran bunga. Dilihat dari standar deviasi yang lebih rendah dari nilai rata-rata (mean) menunjukkan bahwa secara umum bank-bank yang terdaftar di BEI pada periode penelitian memiliki nilai rasio non interest income to total assets dan non interest expense to total assets yang baik, karena memiliki sebaran/penyimpangan yang rendah.

Ratio loan loss provisions to total loans mempunyai nilai rata-rata (mean) sebesar 4.051833 hal tersebut mencerminkan tingkat penyisihan kredit gagal bayar yang masih cukup tinggi, ini mengindikasikan masih tingginya tingkat kredit macet pada sektor perbankan di Indonesia. Dengan standar deviasi sebesar 4.319345 dan lebih besar dari nilai rata-rata (mean) menunjukkan bahwa secara umum bank-bank yang terdaftar di BEI pada periode penelitian memiliki nilai rasio loan loss provisions to total loans yang bervariasi atau bisa dikatakan memiliki selisih/penyimpangan yang tinggi dari nilai rata-ratanya.

Ratio equity to total assets mempunyai nilai ratarata (mean) sebesar 9.943333. Dengan nilai rata-rata yang tinggi hal ini mencerminkan bank-bank yang terdaftar di BEI selama periode penelitian memiliki kepemilikan modal sendiri yang cukup tinggi bila dibandingkan dengan assets perusahaan. Standar deviasi sebesar 3.641353, dan nilainya lebih rendah dari nilai rata-rata (mean) hal ini mencerminkan bahwa secara umum rasio equity to total assets memiliki data yang baik karena memiliki sebaran/ penyimpangan yang rendah.

Total assets memiliki nilai rata-rata (mean) sebesar 72,571 milliar rupiah dengan standar deviasi sebesar 107,000. Standar deviasi yang tinggi menunjukkan bahwa secara umum bank-bank yang terdaftar di BEI pada periode penelitian memiliki nilai total assets yang bervariasi atau bisa dikatakan memiliki selisih/penyimpangan yang tinggi dari nilai rata-ratanya, terdapat kesenjangan antara bank yang memiliki total assets terbesar dan yang terkecil, hal tersebut bisa dilihat dari nilai maximum dan minimum pada Tabel 3.

Growth GDP mempunyai nilai rata-rata (mean) sebesar 5.627322, hal tersebut mencerminkan pertumbuhanekonomiIndonesiayang baik, di manaratarata pertumbuhan ekonomi selama periode peneletian positif dan memiliki nilai yang tinggi, dengan standar deviasi sebesar 0.672274 dan nilainya jauh lebih kecil dari rata-rata (mean) growth GDP menunjukkan bahwa secara umum growth GDP Indonesia pada periode penelitian memiliki nilai yang baik, karena memiliki sebaran/penyimpangan yang rendah.

Tabel 3. Analisis Deskriptif Variabel Penelitian

\begin{tabular}{lcrrrr}
\hline & N & Minimum & \multicolumn{1}{c}{ Maximum } & \multicolumn{1}{c}{ Mean } & Std. Deviation \\
\hline ROA & 180 & -12.9 & 5.77 & 1.622 & 1.936969 \\
NII/TA & 180 & 0.16 & 4.03 & 1.169111 & 0.746856 \\
NIE/TA & 180 & 1.08 & 8.68 & 3.572556 & 1.318249 \\
LLP/TL & 180 & 0.88 & 47.56 & 4.051833 & 4.319345 \\
LNTA & 180 & 633.09 & 552,000 & 72,571 & 107,000 \\
EQASS & 180 & -3.3 & 24.8 & 9.943333 & 3.641353 \\
LNGDP & 180 & 4.5459 & 6.457 & 5.627322 & 0.672274 \\
LNMKTCAP & 180 & 460,000 & $3,540,000$ & $1,670,000$ & $1,050,000$ \\
\hline
\end{tabular}


Market capitalization memiliki nilai rata-rata (mean) sebesar 1,670,000 milliar rupiah dengan standar deviasi sebesar 1,050,000. Standardeviasiyang lebih rendah dari nilai rata-rata (mean) menunjukkan bahwa secara umum market capitalization Indonesia pada periode penelitian memiliki nilai yang baik, karena memiliki sebaran/penyimpangan yang rendah, sehingga tidak terjadi kesenjangan market capitalization di dalam periode penelitian.

\section{Uji Asumsi Klasik}

Uji normalitas dilakukan dengan analisis penyebaran data pada grafik histogram dan normal probability plot. Pengujian normalitas juga dilakukan secara statistik untuk mendapatkan hasil yang lebih valid, yaitu dengan uji statistik non-parametrik Kolmogorov-Smirnov. Data dikatakan normal jika nilai signifikan lebih besar dari 0,05 . Hasil pengujian statistik Kolmogorov-Smirnov, bahwa data telah terdistribusi secara normal. Hal ini ditunjukkan oleh nilai signifikansi Kolmogorov-Smirnov yang berada di atas 0.05 yaitu sebesar 0.089. Selanjutnya, untuk mendukung hasil uji statistik tersebut, dilakukan pula uji normalitas melalui analisis grafik histogram dan normal probability plot. Setelah dilakukannya casewise diagnostics, model regresi telah terdistribusi secara normal. Hal ini ditunjukkan dari distribusi data yang membentuk seperti lonceng.

Pengujian terhadap adanya multikolinearitas dalam penelitian ini adalah dengan menggunakan nilai tolerance dan variance inflation factor (VIF) pada model regresi. Jika tolerance value lebih dari 0,10 dan VIF kurang dari 10, hal ini menunjukkan bahwa tidak terjadi multikolinearitas. Nilai DurbinWatson adalah sebesar 2.074. Hal ini berarti bahwa model regresi tidak mengindikasikan adanya autokorelasi, karena nilai Durbin Watson (r) terletak pada batas antara du dan 4-du. Model regresi dalam penelitian ini bebas dari gejala heteroskedastisitas, karena tidak ada pola tertentu pada grafik scatterplot tersebut. Titik-titik pada grafik relatif menyebar baik di atas sumbu Y maupun di bawah sumbu Y (tidak terdapat pola tertentu).

\section{Analisis Model}

Analisis regresi linear berganda digunakan untuk mengukur pengaruh antara lebih dari satu variabel prediktor (variabel bebas) terhadap variabel terikat diperlihatkan seperti pada Tabel 4.
Tabel 4. Output Model Regresi

\begin{tabular}{lrrr}
\hline \multicolumn{1}{r}{ Model } & Koefisien & $\mathbf{T}$ & Sig. \\
\hline (Constant) & 2.086 & .624 & .534 \\
NII & .142 & .860 & .391 \\
NIE & -.442 & -5.869 & .000 \\
LLP & -.208 & -8.255 & .000 \\
EQUITY & .150 & 5.584 & .000 \\
TA & .505 & 8.059 & .000 \\
GDP & .137 & .773 & .440 \\
MCAP & -.426 & -2.288 & .023 \\
\hline
\end{tabular}

Berdasarkan hasil regresi linear berganda tersebut, model persamaan regresi yang dihasilkan adalah:

$$
\begin{aligned}
\mathrm{ROA}= & 2.086+0.142 \mathrm{NII}-0.442 \mathrm{NIE}-0.208 \mathrm{LLP} \\
& +0.150 \text { Equity }+0.505 \mathrm{LNTA}+0.137 \text { GDP } \\
& -0.426 \text { LNMCAP }+\varepsilon
\end{aligned}
$$

Pada koefisien determinasi model regresi diperoleh nilai $\mathrm{R}$ square sebesar 0.603 . Hal ini berarti bahwa variabel independen non interest income, non interest expense, loan loss provisions, equity, total assets, GDP, market capitalization mampu menjelaskan variabel ROA sebesar $60.3 \%$, sedangkan sisanya dipengaruhi oleh faktor lain yang tidak diteliti. Hasil uji statistik F ditunjukkan pada Tabel 5.

Tabel 5. Hasil Uji Statistik F

\begin{tabular}{lrrrrrr}
\hline Model & \multicolumn{1}{c}{$\begin{array}{c}\text { Sum of } \\
\text { Squares }\end{array}$} & \multicolumn{1}{c}{ df } & $\begin{array}{c}\text { Mean } \\
\text { Square }\end{array}$ & F & Sig. \\
\hline & Regression & 399.798 & 7 & 57.114 & 37.252 & $.000^{\mathrm{b}}$ \\
1 Residual & 263.704 & 172 & 1.533 & & \\
Total & 663.502 & 179 & & & \\
\hline
\end{tabular}

a. Dependent Variabel: ROA

b. Predictors: (Constant), MCAP, NII, NIE, EQUITY, LLP, TA, GDP

Berdasarkan hasil uji statistik tersebut, diketahui nilai $\mathrm{F}$ sebesar 37.252 dengan tingkat signifikansi $0.000(<0.05)$. Hal ini berarti bahwa variabel independen yang terdiri non interest income, non interest expense, loan loss provisions, equity, total assets, GDP, market capitalization secara bersamasama berpengaruh secara signifikan terhadap variabel dependen, yaitu ROA. Hal ini menunjukkan bahwa model regresi dalam penelitian ini benar-benar dapat diterima dan digunakan untuk memprediksi. 


\section{PEMBAHASAN}

Pengaruh Non Interest Income to Total Assets, Non Interest Expense to Total Assets, Loan Loss Provisions to Total Loans, Equity to Total Assets, Total Assets, Growth GDP, dan Market Capitaliztion terhadap Return on Assets (ROA)

Secara simultan, variabel Non Interest Income to Total Assets, Non Interest Expense to Total Assets, Loan Loss Provisions to Total Loans, Equity to Total Assets, Total Assets, Growth GDP, dan Market Capitalization berpengaruh signifikan terhadap Profitabilitas (ROA). Nilai $\mathrm{R}^{2}$ dari model adalah sebesar 0.603 . Hal ini menunjukkan bahwa kemampuan variabel-variabel independen dalam menjelaskan terjadinya volatility varians/fluktuasi yang terjadi pada variabel dependen adalah sebesar $60.3 \%$, sedangkan sisanya, yaitu 39.7\% dijelaskan oleh variabel-variabel lain di luar model.

Hasil penelitian ini membuktikan bahwa variabel non interest income to total assets, non interest expense to total assets, loan loss provisions to total loans, equity to total assets, total assets, growth GDP, dan market capitaliztion berpengaruh signifikan terhadap profitabilitas (ROA), hasil ini sama seperti penelitian yang diungkapkan oleh Sufian and Chong (2008), mengenai faktor penentu profitabilitas pada negara berkembang, dalam penelitiannya bahwa secara simultan variabel variabel non interest income to total assets, non interest expense to total assets, loan loss provisions to total loans, equity to total assets, total assets, growth GDP, dan market capitalization berpengaruh signifikan terhadap profitabilitas.

\section{Pengaruh Non Interest Income terhadap Profitabilitas}

Secara parsial pengujian menunjukkan bahwa variabel rasio non interest income to total assets memiliki pengaruh yang sangat kecil terhadap profitabilitas (ROA), dengan koefisien yang positif. Hubungan positif ini menunjukkan bahwa peningkatan rasio non interest income to total assets akan meningkatkan tingkat profitabilitas (ROA) perusahaan. Hubungan positif non interest income terhadap profitabilitas bank sesuai dengan penelitian Sufian and Chong (2008), di dalam penelitian berpendapat, bahwa dalam beberapa tahun terakhir lembaga keuangan terutama perbankan telah semakin meningkatkan pendapatan yang didapat selain dari bunga, dan hasil yang diperoleh dalam penelitiannya, yaitu rasio non interest income to total assets berpengaruh positif terhadap profitabilitas perbankan.

Non interest income merupakan variabel yang dapat menjelaskan mengenai diversifikasi bisnis yang dilakukan bank selain dari bunga, hal ini karena kegiatan utama bank dan pendapatan utama bank berhubungan dengan bunga, sehingga pendapatan selain dari bunga bisa dinamakan diversivikasi bisnis atau kegiatan usaha lain yang dilakukan bank. Selain dapat meningkatkan pendapatan, non interest income juga dapat berfungsi untuk mengurangi risiko dengan melakukan diversifikasi pada berbagai usaha. Dengan semakin bertambahnyanon interest income, maka akan meningkatkan pendapatan total perbankan yang pada akhirnya akan meningkatkan profitabilitas (ROA) bank, selain itu dengan memperoleh pendapatan dari berbagai kegiatan-kegiatan usaha lain maka apabila terjadi kerugian pada satu kegiatan usaha, bank akan tetap mendapatkan pendapatan dari kegiatan usaha lainnya, sehingga dapat mengurangi risiko yang ada.

Berdasarkan hasil uji determinasi parsial menunjukkan bahwa pengaruh variabel rasio non interest income to total assets terhadap terjadinya fluktuasi yang terjadi pada variabel ROA adalah sebesar $0.99 \%$, pengaruhnya sangat kecil terhadap ROA, hal ini bisa disebabkan karena bank-bank di Indonesia masih mengutamakan pendapatan yang berasal dari bunga, sedangkan pendapatan yang bukan berasal dari bunga masih rendah.

\section{Pengaruh Non Interest Expense terhadap Profitabilitas}

Variabel rasio non interest expense to total assets memiliki koefisien negatif, hal ini menunjukkan bahwa peningkatan rasio non interest expense to total assets akan mengurangi profitabilitas (ROA) perusahaan. Hasil ini sesuai dengan penelitian yang dilakukan oleh Sufian and Chong (2008), dalam hasil penelitiannya rasio non interest expense to total assets memiliki pengaruh negatif signifikan terhadap profitabilitas perbankan (ROA), dengan semakin meningkatnya biaya yang dikeluarkan perusahaan maka akan mengurangi tingkat profitabilitas perusahaan. Pasiouras dan Kosmidou (2007), dan Kosmidou (2008), berpendapat bahwa manajemen biaya yang buruk menjadi salah satu penyebab utama dalam rendahnya profitabilitas. Manajemen biaya yang efisien adalah salah satu syarat penting bagi perusahaan dalam meningkatkan profitabilitas perusahaan di sektor keuangan. 
Non interest expense merupakan biaya yang dikeluarkan oleh bank selain biaya bunga, porsi terbesar dari biaya non bunga adalah gaji, tunjangan, biaya menjalankan fasilitas kantor cabang, dan lain-lain. Pengaruh negatif terhadap profitabilitas perusahaan, karena semakin tinggi non interest expense, maka akan mengurangi laba perusahaan, karena non interst expense merupakan biaya yang harus dikeluarkan perusahaan. Dengan demikian, peningkatan non interest expense perusahaan akan meningkatkan biaya total perusahaan yang selanjutnya biaya tersebut dapat mengurangi tingkat profitabilitas perbankan. Untuk meningkatkan profitabilitas, perusahaan berusaha untuk menjadi lebih produktif dan efisien yang bertujuan untuk meminimalkan biaya operasional mereka, seperti penggunaan teknologi elektronik baru, seperti ATM dan sarana otomatis jasa pengiriman lainnya, mungkin telah menyebabkan biaya upah turun. Ini sesuai dengan teori bahwa semakin efisien pengelolaan biaya oprasional, maka akan semakin tinggi pula profitabilitas yang akan di dapat oleh sebuah bank.

Berdasarkan hasil uji determinasi parsial menunjukkan bahwa pengaruh variabel rasio non interest expense to total assets terhadap terjadinya fluktuasi yang terjadi pada variabel ROA adalah sebesar $12.696 \%$.

\section{Pengaruh Loan Loss Provisions terhadap Profitabilitas}

Secara parsial menunjukkan bahwa variabel rasio loan loss provisions to total assets memiliki pengaruh negatif terhadap profitabilitas perusahaan (ROA), hal ini menunjukkan bahwa peningkatan rasio loan loss provisions to total loans akan mengurangi tingkat profitabilitas perusahaan (ROA). Hasil ini sesuai dengan penelitian yang dilakukan oleh Sufian and Chong (2008), dalam penelitiannya rasio loan loss provisions to total loans memiliki pengaruh negatif dan signifikan terhadap profitabilitas (ROA), hasil penelitian menunjukkan bahwa pada perusahaan perbankan yang memiliki risiko kredit yang lebih tinggi cenderung menunjukkan tingkat profitabilitas yang rebih rendah.

Peningkatan loan loss provisions akan menurunkan tingkat profitabilitas perusahaan (ROA), sebab loan loss provisions merupakan dana yang harus disisihkan oleh bank yang besaran minimalnya telah ditetapkan oleh BI, semakin besar kredit yang disalurkan dan semakin tinggi tingkat risiko kredit, maka penyisihan penghapusan kredit yang diwajibkan pun akan semakin tinggi, oleh karena itu maka apabila penetapan loan loss provisions yang besar akan memengurangi ketersediaan bank untuk menyediakan dana dalam proses penyaluran kredit, dan alokasi dana lain, karena dana yang disisihkan tidak dapat dipergunakan. Dengan demikian, dengan berkurangnya keterediaan dana tersebut, maka akan mengurangi kemampuan bank untuk meningkatkan profitabilitas, selain itu tingginya loan loss provisions menandakan tingginya tingkat risiko kredit atau tingginya tingkat kemungkinan terjadinya gagal bayar (kredit macet), dengan tingginya risiko gagal bayar pada perusahaan perbankan, maka akan menurunkan tingkat profitabilitas (ROA).

Berdasarkan hasil uji determinasi parsial menunjukkan bahwa pengaruh variabel rasio loan loss provisions terhadap terjadinya fluktuasi yang terjadi pada variabel ROA adalah sebesar $17.93 \%$.

\section{Pengaruh Equity terhadap Profitabilitas}

Secara parsial menunjukkan bahwa equity to total assets memiliki pengaruh positif terhadap profitabilitas perusahaan (ROA), hal ini menunjukkan bahwa peningkatan rasio equity to total assets akan meningkatkan profitabilitas perusahaan (ROA). Hasil ini sesuai dengan penelitian yang dilakukan oleh Sufian and Chong (2008), dalam penelitiannya rasio equity total assets memiliki pengaruh positif dan signifikan terhadap profitabilitas (ROA), penelitian ini juga sesuai dengan Staikouras, et al. (2003), Goddard, et al. (2004), Pasiouras and Kosmidou (2007), dan Kosmidou (2008), bank dengan equity yang tinggi memiliki risiko bankrut yang lebih rendah dan mengurangi biaya dari segi pendanaan.

Peningkatan rasio equity to total assets akan meningkatkan profitabilitas perusahaan (ROA). Bank-bank yang memiliki rasio equity to total assets lebih besar dapat lebih mudah dalam melakukan pengembangan usaha karena dengan equity yang dimiliki, bank dapat mengembangkan usahanya yang bertujuan untuk meningkatkan profitabilitas bank, selain itu dengan equity yang tinggi pada sektor perbankan maka akan mengurangi biaya dalam pendanaan perusahaan. Jika perusahaan memiliki equity yang rendah, maka perusahaan akan sulit melakukan pengembangan usahannya/ekspansi, apabila perusahaan ingin mengembangkan usahannya maka bank memerlukan dana dari pihak lain namun harus mengeluarkan biaya yang lebih tinggi untuk 
memperolehnya, oleh karena itu perusahaan harus memiliki equity yang cukup.

Struktur permodalan yang kuat juga sangat penting bagi lembaga keuangan di negara berkembang yang rentan terhadap dampak krisis dari negara lain, hal ini karena dapat memberikan kekuatan tambahan dalam bertahan pada kondisi krisis keuangan dan dapat pula meningkatkan keamanan terhadap deposan selama kondisi makro ekonomi yang tidak stabil. Selain itu, rasio modal yang lebih rendah di bidang perbankan mengindikasikan leverage dan risiko yang lebih tinggi, yang karenanya mengakibatkan biaya pinjaman yang lebih besar.

Berdasarkan hasil uji determinasi parsial menunjukkan bahwa pengaruh variabel rasio equity to total assets terhadap terjadinya fluktuasi yang terjadi pada variabel ROA adalah sebesar $7.70 \%$.

\section{Pengaruh Total Assets terhadap Profitabilitas}

Secara parsial menunjukkan bahwa total assets memiliki pengaruh positif terhadap profitabilitas perusahaan (ROA), hal ini menunjukkan bahwa peningkatan total assets akan meningkatkan profitabilitas perusahaan (ROA). Hasil ini tidak konsisten dengan penelitian yang dilakukan oleh Sufian and Chong (2008), dalam penelitiannya total assets memiliki pengaruh negatif terhadap profitabilitas (ROA) perbankan, pengaruh negatif menunjukkan bahwa semakin besar suatu bank (total asset), maka bank cenderung untuk mendapatkan profitabilitas (ROA) yang lebih rendah, hal ini bisa disebabkan karena diseconomies of scale bagi bank yang lebih besar (Pasiouras and Kosmidou, 2007).

Namun dalam penelitiannya, Hauner (2004), Ramlall (2009), menemukan hubungan positif antara total assets dengan profitabilitas (ROA) bank. Hal ini karena terjadinya skala ekonomi. Eichengreen and Gibson (2001), menurutnya pengaruh ukuran bank (total assets) terhadap profitabilitas akan positif sampai pada batas tertentu, di luar titik ini dampak dari ukuran bank bisa menjadi negatif.

Peningkatan total assets perusahaan akan meningkatkan profitabilitas (ROA). Hubungan positif antara total asset dengan ROA ini terjadi karena terjadinya economics of scale, yaitu turunnya biaya per unit akibat peningkatan ukuran atau skala usaha operasi perusahaan. Tingginya tingkat output menyebabkan biaya per unit turun karena kapasitas produksi dan sumber daya manusia dapat digunakan secara maksimal. Begitu pula dengan perusahaan jasa finansial seperti bank sebagai badan usaha, maka bank akan berperilaku bahwa semakin besar skala operasi usaha sebuah bank maka akan semakin berkembang karena dapat beroperasi secara efisien.

Berdasarkan hasil uji determinasi parsial menunjukkan bahwa pengaruh total assets terhadap terjadinya fluktuasi yang terjadi pada variabel ROA adalah sebesar $22.41 \%$. Variabel total assets memiliki pengaruh tertinggi terhadap terjadinya fluktuasi ROA.

\section{Pengaruh Gross Domestic Product terhadap Profitabilitas}

Secara parsial menunjukkan bahwa growth GDP memiliki pengaruh positif terhadap profitabilitas perusahaan (ROA), hal ini menunjukkan bahwa peningkatan Growth GDP akan meningkatkan profitabilitas perusahaan (ROA). Hasil ini sesuai dengan penelitian yang dilakukan oleh Sufian and Chong (2008), menurutnya growth GDP diperkirakan akan mempengaruhi beberapa faktor yang berhubungan dengan penawaran dan permintaan pinjaman dan deposit. Dengan pertumbuhan GDP melambat terutama selama resesi, kualitas kredit memburuk, dan kredit macet meningkat, sehingga akan mengurangi keuntungan bank.

Pertumbuhan ekonomi (growth GDP) memiliki pengertian sebagai suatu proses peningkatan barang dan jasa di dalam suatu perekonomian. Semakin tinggi nilainya, maka akan semakin tinggi pula tingkat produktifitas suatu negara, perputaran arus barang dan jasa semakin cepat dan besar. Dalam proses ini bank ikut berfungsi sebagai lembaga intermediaris yang menjadi salah satu pendukung proses tersebut.

Peningkatan growth GDP akan meningkatkan profitabilitas perusahaan (ROA), semakin tinggi tingkat pertumbuhan ekonomi (GDP) Indonesia, maka akan meningkatkan tingkat profitabilitas perbankan di Indonesia. Pertumbuhan ekonomi akan meningkatkan permintaan atas kredit perbankan, hal ini karena kegiatan ekonomi yang mengalami peningkatan produksi barang dan jasa membutuhkan sumber pembiayaan, dan ini dapat diberikan oleh bank melalui penyaluran kredit, dengan meningkatnya permintaan atas kredit, maka bank akan memperoleh peningkatan pendapatan dari bunga kredit tersebut, dengan peningkatan laba perusahaan maka tingkat profitabilitas bank akan semakin meningkat. Selain itu semakin tinggi pertumbuhan ekonomi suatu negara, maka dapat dikatakan masyarakatnya semakin sejahtera, sehingga meningkatkan investasi 
dan saving yang salah satunya dilakukan melalui bank. Kondisi ini dapat dimanfaatkan bank untuk mengelola dana yang berhasil dihimpunnya untuk disalurkan kembali melalui kredit dan kegiatan usaha lainnya yang bertujuan untuk mendapatkan pendapatan perusahaan yang pada akhirnya akan meningkatkan profitabilitas.

Berdasarkan hasil uji determinasi parsial menunjukkan bahwa pengaruh growth GDP terhadap terjadinya fluktuasi yang terjadi pada variabel ROA adalah sebesar $0.56 \%$.

\section{Pengaruh Market Capitalization terhadap Profitabilitas}

Secara parsial menunjukkan bahwa market capitalization memiliki pengaruh negatif terhadap profitabilitas perusahaan (ROA), hal ini menunjukkan bahwa peningkatan market capitalization akan menurunkan tingkat profitabilitas perusahaan (ROA). Hasil tidak konsisten dengan penelitian yang dilakukan oleh Sufian and Chong (2008), DemirgüçKunt and Huizinga (1999) menemukan bahwa market capitalization memiliki hubungan negatif terhadap profitabilitas perbankan, hal itu karena pasar saham yang relatif berkembang dengan baik dapat menggantikan pembiayaan bank, sehingga dengan peningkatan nilai kapitalisasi pasar akan menyebabkan penurunan tingkat profitabilitas bank.

Peningkatan nilai market capitalization di Bursa Efek Indonesia (BEI) akan memberikan pengaruh penurunan profitabilitas perbankan, kapitalisasi pasar yang memiliki dampak negatif terhadap ROA pada bank-bank yang terdaftar di BEI disebabkan karena pasar modal dan pembiayaan bank memiliki hubungan substitusi atau pengganti. Setiap perusahaan memerlukandanauntukmelakukan kegiatanusahanya, ketika suatu perusahaan memerlukan dana untuk melakukan kegiatan usahannya, misal ekspansi usaha, membayar utang, membiayai kegiatan perusahaan, dan lain-lain, maka bank dapat memperoleh dana dari pihak lain, selain dapat meminjam dana ke bank, perusahaan juga dapat menjual sahamnya di Bursa Efek Indonesia (BEI) untuk mendapatkan dana dari hasil penjualan sebagian saham perusahaannya.

Dengan listing-nya perusahaan tersebut, maka nilai kapitalisasi pasar di Bursa Efek Indonesia akan semakin bertambah, terutama bila perusahaan tersebut perusahaan besar maka nilai kapitalisasi pasar di BEI akan lebih meningkat, selain itu pasar saham yang berkembang dengan baik akan memiliki nilai kapitalisasi pasar yang tinggi, sehingga akan memberikan sinyal yang baik kepada perusahaan lain untuk melakukan listing di bursa atau malakukan penjualan kembali sahamnya, yang pada akhirnya akan meningkatkan pembiayaan melalui pasar modal dan akan mengurangi pembiayaan dari bank. Dengan berkurangnya pembiayaan oleh bank maka pendapatan yang berasal dari bunga kredit akan berkurang sehingga profitabilitas bank akan juga akan berkurang.

Market capitalization yang berkembang dengan baik akan membuat masyarakan lebih tertarik untuk melakukan investasi di pasar modal dengan membeli saham-saham perusahaan dibandingkan dengan berinvestasi pada perbankan (misal saving, deposito, dan lain-lain), sehingga permintaan akan saham meningkat yang selanjutnya akan meningkatkan nilai market capitalization, karena berkurangnya dana yang disimpan/diinvestasikan di bank, maka dana pihak ketiga yang dimiliki bank akan berkurang, sehingga dana yang digunakan untuk penyaluran kredit pun akan berkurang, oleh karena itu kondisi pasar modal yang baik yang dapat dilihat dengan nilai kapitalisasai pasar yang tinggi dapat menggantikan pembiayaan bank, sehingga akan memiliki dampak negatif terhadap profitabilitas bank.

Berdasarkan hasil uji determinasi parsial menunjukkan bahwa pengaruh variabel market capitalization terhadap terjadinya fluktuasi yang terjadi pada variabel ROA adalah sebesar $1.6 \%$

\section{KESIMPULAN}

Pengaruh rasio non interest income to total assets terhadap ROA secara parsial, variabel rasio non interest income to total assets memiliki pengaruh positif terhadap profitabilitas (ROA). Selain meningkatkan pendapatan, non interest income juga dapat berfungsi untuk mengurangi risiko dengan melakukan diversifikasi pada berbagai usaha. Dengan semakin bertambahnya rasio non interest income to total assets maka akan meningkatkan pendapatan total perbankan yang pada akhirnya akan meningkatkan tingkat profitabilitas (ROA) bank. Rasio non interest income to total assets memiliki pengaruh terkecil terhadap terjadinya fluktuasi yang terjadi pada variabel ROA. Hal ini bisa disebabkan karena bankbank di Indonesia masih mengutamakan pendapatan yang berasal dari bunga, sedangkan pendapatan yang bukan berasal dari bunga masih rendah. 
Pengaruh rasio non interest expense to total assets terhadap ROA decara parsial, variabel rasio non interest expense to total assets memiliki pengaruh negatif terhadap profitabilitas (ROA) perusahaan, hal ini menunjukkan bahwa peningkatan rasio non interest expense to total assets akan menurunkan profitabilitas (ROA) perusahaan. Pengaruh negatif terhadap profitabilitas perusahaan karena semakin tinggi non interest expense maka akan mengurangi laba perusahaan karena non interest expense merupakan biaya yang harus dikeluarkan perusahaan. Sehingga peningkatan non interest expense perusahaan akan meningkatkan biaya total perusahaan yang selanjutnya biaya tersebut dapat mengurangi tingkat profitabilitas perbankan. Untuk meningkatkan profitabilitas, perusahaan berusaha untuk menjadi lebih produktif dan efisien yang bertujuan untuk meminimalkan biaya operasional mereka.

Pengaruh rasio loan loss provisions to total loans terhadap ROA secara parsial, variabel rasio loan loss provisions to total loans memiliki pengaruh negatif terhadap profitabilitas (ROA) perusahaan, hal ini menunjukkan bahwa peningkatan rasio loan loss provisions to total loans akan menurunkan profitabilitas (ROA) perusahaan sebab loan loss provisions merupakan dana yang harus disisihkan oleh bank yang besaran minimalnya telah ditetapkan oleh BI, semakin besar kredit yang disalurkan dan semakin tinggi tingkat risiko kredit maka penyisihan penghapusan kredit yang diwajibkan pun akan semakin tinggi, oleh karena itu maka apabila penetapan loan loss provisions yang besar akan memengurangi ketersediaan bank untuk menyediakan dana dalam proses penyaluran kredit, dan alokasi dana lain, karena dana yang disisihkan tidak dapat dipergunakan. Sehingga dengan berkurangnya keterediaan dana tersebut maka akan mengurangi kemampuan bank untuk meningkatkan profitabilitas, selain itu tingginya loan loss provisions menandakan tingginya tingkat risiko kredit atau tingginya tingkat kemungkinan terjadinya gagal bayar (kredit macet), dengan tingginya risiko gagal bayar pada perusahaan perbankan maka akan menurunkan tingkat profitabilitas (ROA).

Pengaruh rasio equity to total assets terhadap ROA secara parsial, variabel rasio equity to total assets memiliki pengaruh positif terhadap profitabilitas (ROA) perusahaan, hal ini menunjukkan bahwa peningkatan rasio equity total assets akan meningkatkan profitabilitas (ROA) perusahaan. Struktur permodalan yang kuat sangat penting bagi lembaga keuangan di Negara berkembang, karena dapat memberikan kekuatan tambahan dalam bertahan pada kondisi krisis keuangan dan juga dapat meningkatkan keamanan terhadap deposan selama kondisi makro ekonomi yang tidak stabil. Selain itu, rasio modal yang lebih rendah di bidang perbankan mengindikasikan leverage dan risiko yang lebih tinggi, yang karenanya mengakibatkan biaya pinjaman yang lebih besar. Bank yang memiliki equity lebih besar dapat lebih mudah dalam pengembangan usaha karena dengan equity yang dimiliki, bank dapat mengembangkan usahanya yang bertujuan untuk meningkatkan profitabilitas bank. Dengan demikian, semakin tinggi tingkat equity pada bank-bank go public maka akan meningkatkan tingkat profitabilitas bank tersebut.

Pengaruh total assets terhadap ROA secara parsial, variabel total assets memiliki pengaruh positif terhadap profitabilitas (ROA) perusahaan, hal ini menunjukkan bahwa peningkatan rasio total assets akan meningkatkan profitabilitas (ROA) perusahaan. Hubungan positif antara total assets dengan ROA ini terjadi karena terjadinya economics of scale yaitu turunnya biaya per unit akibat peningkatan ukuran atau skala usaha operasi perusahaan. Tingginya tingkat output menyebabkan biaya per unit turun karena kapasitas produksi dan sumber daya manusia dapat digunakan secara maksimal. Begitu pula dengan perusahaan jasa finansial seperti bank sebagai badan usaha, maka bank akan berperilaku bahwa semakin besar skala operasi usaha sebuah bank maka akan semakin berkembang karena dapat beroperasi secara efisien. Total assets memiliki pengaruh terbesar terhadap terjadinya fluktuasi yang terjadipada variabel ROA.

Pengaruh Growth GDP terhadap ROA secara parsial, variabel Growth GDP memiliki pengaruh positif terhadap profitabilitas (ROA) perusahaan, hal ini menunjukkan bahwa peningkatan Growth GDP akan meningkatkan profitabilitas (ROA) perusahaan. Pertumbuhan ekonomi meningkatkan permintaan atas kredit perbankan, hal ini karena kegiatan ekonomi yang mengalami peningkatan produksi barang dan jasa membutuhkan sumber pembiayaan, dan ini dapat diberikan oleh bank melalui penyaluran kredit. Selain itu semakin tinggi pertumbuhan ekonomi suatu negara, maka dapat dikatakan masyarakatnya 
semakin sejahtera sehingga meningkatkan investasi dan saving yang salah satunya dilakukan melalui bank. Kondisi ini dapat dimanfaatkan bank untuk mengelola dana yang berhasil dihimpunnya untuk mendapatkan profitabilitas yang tinggi.

Pengaruh market capitalization terhadap ROA secara parsial, variabel market capitalization memiliki pengaruh negatif terhadap profitabilitas (ROA) perusahaan, hal ini menunjukkan bahwa peningkatan market capitalization akan menurunkan profitabilitas (ROA) perusahaan. Kapitalisasi pasar yang memiliki dampak negatif terhadap ROA bank-bank yang terdaftar di BEI disebabkan karena pasar modal dan pembiayaan bank memiliki hubungan substitusi atau pengganti, sehingga kondisi pasar modal yang baik yang dapat dilihat dengan nilai kapitalisasai pasar yang tinggi dapat menggantikan pembiayaan bank, sehingga akan memiliki dampak negatif terhadap profitabilitas bank.

Pengaruh non interest income to total assets, non interest expense to total assets, loan loss provisions to total loans, equity to total assets, total assets, Growth GDP, dan market capitaliztion terhadap return on assets (ROA) secara simultan, berpengaruh signifikan terhadap Profitabilitas (ROA).

\section{DAFTAR PUSTAKA}

Abreu, M. and Mendes V. 2002. Commercial bank interest margins and profitability: evidence from E.U. Countries. University of Porto Working Paper Series, 245.

Arifin, Imamul dan Giana Hadi W. 2007. Membuka Cakrawala Ekonomi. Bandung: PT Grafindo.

Demirgüç-Kunt, Ash and Harry Huizinga. 1999. Determinants of Commercial Bank Interest Margins and Profitability: Some International Evidence. The World Bank Economic Review, 13(2): 379-408.

Dietrich, Andreas and Gabrielle Wanzenried. 2009. What Determines the Profitability of Commercial Banks? New Evidence from Switzerland. IFZ Working Paper, 10.

Eichengreen, B. dan Gibson, H. D. 2001. Greek Banking at the Dawn of the New Millennium. CERP Discussion Paper, 2791.

Flamini, Valentina, Calvin McDonald, and Liliana Schumacher. 2009. The Determinants of Commercial Bank Profitability in Sub-Saharan Africa. IMF Working Paper.
Goddard, J., Molyneux, P. and Wilson, J. 2004. Dynamics of Growth and Profitability in Banking. Journal of Money, Credit and Banking, 36: 10691090.

Hauner, David. 2004. Explaining Efficiency Differences Among Large German and Austrian Commercial Banks. Applied Economics, 37(9): 969-980.

Husnan, Suad dan Enny Pudjiastuti. 2004. Dasardasar Manajemen Keuangan (Edisi ke-6) Yogyakarta: UPP STIM YKPN.

Jiang, Guorong, Nancy Tang, Eve Law and Angela Sze. 2003. The Profitability of the Banking Sector in Hong Kong. Hong Kong Monetary Authority Quarterly Bulletin: 5-14.

Kaya, T. Y. 2002. Determinants of Profitability in Turkish Banking Sector. Turkish Banking Regulation and Supervision Agency, 1.

Kosmidou, K. 2008. The Determinants of Banks Profits in Greece During the Period of EU Financial Integration. Managerial Finance, 34(3): 146-159.

Manurung, Adler Haymans. 2009. Berinvestasi dan Perlindungan Investor di Pasar Modal. Jakarta: IKPIA Perbanas.

Margaretha, Farah. 2006. Manajemen Keuangan bagi Industri Jasa. Jakarta: PT Widiasarana Indonesia (Grasindo).

Mishkin, Frederic S. 2011. Economics of Money, Banking and Financial Markets ( $9^{\text {th }}$ edition). Prentice Hall.

Molyneux, Philip and John Thornton. 1992. Determinants of European Bank Profitability: A Note. Journal of Banking and Finance, 16: 11731178.

Pasiouras, F. and Kosmidou, K. 2007. Factors Influencing the Profitability of Domestic and Foreign Commercial Banks in the European Union. International Business and Finance, 21: 222-237.

Ramlall, I. 2009. Bank-Specific, Industry-Specific and Macroeconomic Determinants of Profitability in Taiwanese Banking System: Under Panel Data Estimation. International Research Journal of Finance and Economics, (34): 160-167.

Riyanto, Bambang. 2001. Dasar-dasar Pembelanjaan Perusahaan. Yogyakarta: BPFE.

Sekaran, Uma. 2007. Research Methods for Business. Jakarta: Penerbit Salemba Empat.

Sholihin, Ahmad Ifham. 2010. Buku Pintar Ekonomi Syariah. Jakarta: PT Gramedia Pustaka Utama. 
Siamat, Dahlan. 2001. Manajemen lembaga Keuangan. Jakarta: Fakultas Ekonomi Universitas Indonesia.

Staikouras, C., Smith, R. and G. Wood. 2003. NonInterest Income and Total Income Stability. Bank of England Quarterly Bulletin 43, 198.
Sufian, Fadzlan and Royfaizal Razali Chong. 2008. Determinants of Bank Profitability in A Developing Economy: Empirical Evidence From The Philippines. Asian Academy of Management Journal of Accounting and Finance, 4(2): 91112. 